\title{
ACOLHIMENTO INSTITUCIONAL NA ASSISTÊNCIA À INFÂNCIA: O COTIDIANO EM QUESTÃO
}

\author{
ACOGIDA INSTITUCIONAL EN LA ASISTENCIA DE LA INFANCIA: EL \\ COTIDIANO EN CUESTIÓN \\ INSTITUTIONAL CARE IN THE ASSISTANCE TO CHILDHOOD: THE \\ EVERYDAY IN QUESTION
}

Carina Ferreira Guedes e Ianni Regia Scarcelli Universidade de São Paulo, São Paulo/SP, Brasil

\begin{abstract}
RESUMO
Tendo como referência o trabalho desenvolvido em uma instituição de acolhimento para crianças e adolescentes, este artigo reflete sobre o cotidiano desses serviços a partir da discussão sobre o lugar no discurso social em que são colocadas as crianças e suas famílias, bem como a instituição e seus agentes. A hipótese trabalhada é de que os diversos momentos cotidianos são constituídos por modelos de práticas sociais que formaram a assistência à infância - a caritativa, a filantrópica e a do Estado de bem-estar social -, cada uma atribuindo, em seu discurso, posições específicas aos envolvidos. São retomados esses modelos de assistência, de forma a evidenciar os eixos centrais pelos quais se constituem. Em seguida, é discutida essa hipótese a partir de cenas desse dia a dia, de modo a pensar como a problematização dessas posições pode permitir um outro lugar na escuta e nas práticas de psicólogos nas instituições de acolhimento institucional.
\end{abstract}

Palavras-chave: acolhimento institucional; políticas públicas; Estatuto da Criança e do Adolescente; institucionalização; práticas sociais.

\section{RESUMEN}

En relación con el trabajo en un centro de acogida para niños y adolescentes, este artículo reflexiona sobre la vida cotidiana de estos servicios a partir de la discusión sobre el lugar en el discurso social en el que se colocan los niños y sus familias, así como a la institución y sus agentes. La hipótesis es que los diversos momentos cotidianos son elaborados por los modelos de prácticas sociales que formaban la asistencia del infancia -caritativo, filantrópico y Estado de Bienestar Social -, asignando a cada uno, en su discurso, a los puestos específicos involucrados. Son recogido estos modelos, destacando los ejes centrales por los cuales se constituyen. A continuación, estas hipótesis son discutidas desde escenas de ese día a día, por lo que pensar lo problemático de estas posiciones puede permitir otro lugar de la escucha y la práctica de los psicólogos en las instituciones de acohida institucional.

Palabras clave: acogida institucional; políticas públicas; Estatuto del Niño y del Adolescente; institucionalización.

\begin{abstract}
This research brings a reflexion on daily children and adolescents care based on the work developed in an institution (shelter). It is based on the emplacement of children and their family, as well as the institution and their agents, into the social discourse. The hypothesis adopted here is that several social practices in these institutions consist on practice models that framed childhood assistance - the charitable, the philanthropic and the State of social welfare -, each one assigning specific positions to families and institutional agents. These models are recapitulated, in order to highlight the central axes for which constitute. Then, this hypothesis is discussed using information from these day-to-day events in order to consider how the questioning of these positions may allow another positioning in listening and in the practices of psychologists in institutional care institutions.
\end{abstract}

Keywords: shelters; public politics; Children and Adolescent Code; institutionalization; social practices. 
Este trabalho consiste em uma reflexão sobre o acolhimento institucional na assistência à infância a partir da discussão de cenas vividas por uma das pesquisadoras em sua experiência de trabalho como psicóloga em um Serviço de Acolhimento Institucional para Crianças e Adolescentes (SAICA).

Na última década, o campo da assistência social, como política pública no Brasil, tem sido marcado pela implementação do Sistema Único de Assistência Social (Ministério do Desenvolvimento Social e Combate à Fome, 2005), com a criação, a municipalização e o reordenamento de serviços. Tendo em vista a especificidade desse momento, torna-se relevante refletir sobre a ação dos psicólogos nessas instituições, de modo a auxiliar na construção de referenciais que possam nortear uma ética para essa atuação.

O trabalho nas instituições de acolhimento institucional abrange uma multiplicidade de campos de ação, de forma a contemplar as diferentes esferas das vidas de crianças e adolescentes acolhidos. Interlocuções com profissionais da educação, saúde e Poder Judiciário são frequentes e necessárias, assim como ações com a família e a comunidade. As relações construídas e os impasses existentes entre funcionários e acolhidos, bem como entre os acolhidos, também constituem-se como importantes campos de trabalho. Tal diversidade permite usufruir dessas diversas relações e contextos, de modo a produzir, a partir delas, diferentes formas de encontros e modos de reconhecimento. Por outro lado, diante dessa abrangência, um risco possível é de que esses campos diferentes de trabalho fragmentem as ações por meio de execuções de tarefas pontuais em contextos aparentemente independentes.

Para que esses diversos campos de ação possam se configurar como espaços de construção, e não de mera reação, torna-se imprescindível questionar sobre seus solos comuns e suas articulações possíveis. A ideia desenvolvida neste artigo prioriza um eixo possível dessa ligação: as posições estabelecidas pelos discursos. A hipótese trabalhada é de que as práticas sociais nessas instituições são constituídas pelo atravessamento do lugar no discurso social em que são colocadas essas famílias e a situação de institucionalização das crianças e adolescentes e, retroativamente, a instituição de acolhimento e seus agentes.

O discurso é entendido como um dispositivo organizador da realidade. Para além de uma relação entre palavra e coisa, constitui-se como um conjunto de regras que, em ato, põe em funcionamento enunciados e relações (Foucault, 1970). A partir das contribuições de Guirado (2009), destaca-se dessa noção de discurso sua correspondência a uma prática que desenha, no seu próprio acontecimento, lugares e subjetividades.

A ideia desenvolvida é de que esses lugares são constituídos em parte pelos modelos discursivos construídos ao longo da história da assistência à infância. Embora em termos históricos as diferentes formas de assistência a essa população tenham prevalecido em momentos distintos, muitas vezes se apresentando como forma de superação uma da outra, a hipótese trabalhada é de que elas se constituem como paradigmas de ação que desenham, cada uma, objetivos específicos às práticas e lugares aos envolvidos. $\mathrm{O}$ objetivo é mostrar como esses modelos de assistência estão presentes nos diversos momentos institucionais e que sua problematização pode permitir um outro lugar na escuta e nas ações nas instituições de acolhimento institucional.

\section{Modelos de assistência à infância: rupturas e complementaridades}

Marcílio (2006) estabelece três fases de assistência e proteção à infância considerada desvalida - a caritativa, a filantrópica e a do Estado do bemestar social - presentes tanto na história europeia quanto na brasileira. A ideia da qual se parte é de que essas formas de assistência à infância constituem-se não como "fases", tal como nomeia Marcílio (2006), que dão margem a uma concepção de substituição ou superação, mas sim como modelos de discursos, que implicam diferentes atribuições de posições discursivas. A partir desse pressuposto, é possível pensar que esses modelos coexistem no cotidiano atual dos serviços, por mais que impliquem concepções muitas vezes contraditórias entre si. Assim, serão apresentados brevemente esses três modelos, procurando-se ressaltar seus eixos centrais.

\section{A assistência caritativa}

Corresponde ao primeiro modelo de assistência à infância, que se iniciou na Europa no século XIII, quando o abandono de crianças tornou-se mais intenso, em especial nos aglomerados urbanos e nas áreas de religião católica. Caracteriza-se pelo predomínio de ações promovidas pela Igreja Católica ou por pessoas individualmente, muitas vezes recorrendo-se à institucionalização dos assistidos (Marcílio, 2006).

No Brasil, a assistência à infância iniciou-se com a colonização, por meio das escolas elementares criadas pelo jesuítas para "civilizar" as crianças indígenas (Chambouleyron, 2000). Já para as crianças abandonadas, filhas da ilegitimidade ou da pobreza, 
foram criadas, a partir do século XVIII, instituições de recolhimento, tais como as Casas dos Expostos, cujo um dos marcos são o recebimento anônimo e incondicional das crianças, além das altíssimas taxas de mortalidade. Também era hábito difundido, valorizado e, muitas vezes, necessário, o costume de criar um filho alheio, já que "pegar um filho para criar" proporcionava também um complemento à mão de obra, mais barato e eficiente que os escravos, dado que ligado por laços de fidelidade e reconhecimento (Marcílio, 2006).

Segundo Marcílio (2006), na assistência caritativa não havia a condenação pelo ato do abandono ou uma preocupação em modificar a ordem vigente. Ao contrário, a ideia disseminada era de que as crianças abandonadas possibilitavam a prática da compaixão, necessária para a salvação da alma do cristão. Tais características de manutenção e legitimação das desigualdades, que transformam a pobreza ou o sofrimento em um mal necessário para poder exercer "o bem", são, de acordo com Caponi (2000), centrais na lógica da compaixão, fundamento das práticas caritativas. Essas se estruturam a partir de uma relação assimétrica, tendo como eixo o binômio servir/obedecer ou ajudar/ser ajudado. Do lado de quem serve, há uma certeza que se conhece o que representa o bem para o outro, acreditando-se ter uma responsabilidade absoluta sobre ele. A quem recebe, é exigido o pagamento dessa dívida, sob forma de reconhecimento, gratidão e obediência ilimitados.

Caponi (2000) sugere uma ambiguidade característica desses projetos: "se, por um lado, se apresentam como uma forma de assistência caridosa dirigida aos necessitados, por outro, se apresentam como dispositivos de controle e coerção social" (p. 27). Como não é autorizado a quem recebe auxílio dizer sobre suas necessidades, fica vetada a possibilidade de um diálogo entre iguais, próprio ao âmbito político. A caridade mostra, assim, sua vertente impositiva, legitimadora de relações assimétricas e sociedades desiguais.

\section{O modelo filantrópico}

Historicamente, as políticas filantrópicas emergiram na Europa no contexto da industrialização e do crescimento dos centros urbanos quando, diante do aumento do abandono de crianças, a demanda de assistência superou em muito as possibilidades de atendê-la. Tal fato, aliado aos pensamentos liberais, utilitaristas e iluministas que afloravam, produziu inúmeras críticas sobre o modo de funcionamento das instituições de caridade, dadas as altíssimas taxas de mortalidade das crianças, que implicavam um gasto público sem retorno (Donzelot, 1980; Marcílio, 2006; Rizzini, 2011), bem como ao modo de funcionamento geral das práticas caritativas, demasiadamente onerosas e ineficientes (Donzelot, 1980).

A política filantrópica surgiu fundada sobre o polo assistencial, transformando direitos sociais em moralidade econômica, e o polo médico higienista. Nesse processo de transformação, os conceitos de família e de infância adquiriram novos significados: a infância deixou de ser objeto de interesse apenas da família ou da Igreja e tornou-se um dos principais instrumentos de intervenção do Estado na família (Donzelot, 1980; Marcílio, 2006; Rizzini, 2011).

No Brasil, as ideias filantrópicas consolidaram-se no período de implementação do modelo republicano. Segundo Rizzini (2011), o Brasil passava por uma fase de emancipação, na busca de sua nacionalidade e de sua identidade nacional. A medicina higienista, aliada ao direito, operou como norteador dessas práticas, avaliando, e julgando, o grau de capacidade e dignidade das famílias em cuidar de seus filhos, de modo a "prevenir" que a infância em perigo se transformasse em uma infância perigosa (Rizzini, 2011; Serra, 2011). Nota-se, nesse modelo, a ênfase no controle, na "prevenção", assim como a fácil transposição do "em perigo" ao "perigoso".

\section{O modelo de bem-estar social}

Marcílio (2006) considera que, embora a promulgação do Código de Menores de 1927 (Decreto n. 17.943, 1927) tenha marcado o lugar de intervenção do Estado nas práticas ligadas à infância, até a década de 60 este não foi um interventor na assistência e na proteção da infância desvalida. Para a autora, foi apenas na década de 1960 que o Brasil tornou-se o principal responsável pela assistência e proteção, estabelecendo uma prática de bem-estar social para os assuntos da infância. Porém, no contexto da ditadura militar, a proteção à infância considerada desvalida e delinquente misturou-se com a Lei de Segurança Nacional, de forma que as premissas em relação às ideias presentes no primeiro Código de Menores não foram modificadas nos planos, legislações e instituições que se sucederam. Ao longo desse período, a institucionalização foi marcada pela falta de critérios nas internações, violência, isolamento da comunidade e ênfase na "correção" e na repressão (Silva, 2004).

Foi apenas no fim dos anos 70, com a abertura democrática, que surgiram movimentos sociais que passaram a denunciar a perversidade e a ineficácia das políticas e das legislações anteriores (Silva, 2004). Na década seguinte, tal visão foi reforçada 
pela nova Constituição Federal (1988) e, dois anos depois, o Estatuto da Criança e do Adolescente (ECA) (Lei Federal n. 8.069, 1990) reafirmou a doutrina da proteção integral, considerando a criança como um sujeito de direitos. Pino (1980) assinala que a promulgação do Estatuto representa um gesto político de conciliação legal do país com sua infância, além de firmar o reconhecimento do direito das crianças à cidadania, independente de sua classe social.

$\mathrm{O}$ grande desafio apontado por autores que se dedicam a estudar o histórico da institucionalização de crianças e sua relação com práticas atuais referese à disparidade entre as legislações vigentes e as ações estabelecidas nas instituições (Fávero, Vitale, \& Baptista, 2008; Rizzini, 2011; Rizzini \& Pilotti, 2011; Silva, 2004), ou seja, entre as políticas públicas e suas práticas sociais correspondentes.

Uma hipótese para essa disparidade diz respeito à possibilidade de complementaridade entre os modelos descritos. Caponi (2000) sugere que entre as práticas assistenciais caritativas e filantrópicas não existe uma ruptura absoluta, muito embora a segunda tenha se apresentado como garantia de superação da primeira. Embora haja diferenças substanciais entre esses modelos, existem continuidades que possibilitam a geração de práticas solidárias, já que ambos colocam seus princípios acima dos sujeitos envolvidos, visto que seu acesso à palavra e ao dizer de si lhe é negado (Caponi, 2000).

Nesse aspecto, é possível notar que, ao menos no âmbito da legislação, a Constituição de 1988 e o ECA (Lei Federal n. 8.069, 1990) são marcos no campo da luta pelo reconhecimento de direito da infância e adolescência do Brasil, mostrando um avanço em relação às diretrizes anteriores. Leôncio (2009) enfatiza que a palavra "sujeito" do termo "sujeito de direitos" traz uma concepção da criança e do adolescente autônomos, íntegros e dotados de personalidade e vontade própria, em contraposição à noção de um indivíduo passivo, subalterno e objeto das ações e decisões. Já o termo "direito" sublinha a existência das ações serem realizadas por direitos sociais, para além da beneficência ou piedade.

Com base nas questões levantadas, é colocado em relevo e sob discussão cenas do cotidiano de uma instituição de acolhimento institucional para crianças e adolescentes.

\section{Mosaico de cenas: considerações metodológicas}

Optou-se, neste trabalho, ter como campo de análise a escrita de cenas e fragmentos da experiência de trabalho de uma das pesquisadoras em um abrigo. Antes de apresentá-las, entretanto, cabem algumas considerações metodológicas sobre o processo de escrita.

A opção por utilizar cenas escritas de uma experiência de trabalho como campo de análise decorre da convicção sobre a importância de produções de conhecimento que tenham como origem os cotidianos institucionais e que retorne a eles trazendo outros prismas de análise e contribuindo para a discussão das práticas realizadas. A aposta é de que esse percurso pode possibilitar a formulação de embasamentos teóricos que efetivamente dialoguem e interpelem as práticas, assim como permitir a elaboração de políticas e programas que considerem a complexidade existente nesse cotidiano, além de promover o compartilhamento e a discussão de questões, dificuldades e aprendizados decorrentes da prática institucional.

É importante explicitar as implicações existentes na passagem do lugar de psicóloga da instituição a pesquisadora, caminho percorrido por uma das autoras, na qual a escrita de cenas e histórias vivenciadas na instituição teve função fundamental. Durante o período de trabalho na instituição, foram registradas descrições e impressões referentes às atividades cotidianas realizadas. O objetivo dessas anotações estava vinculado ao acompanhamento dos casos, a partir do lugar institucional de psicóloga. Após o desligamento da instituição e ingresso no Programa de Pós-Graduação, foi realizada uma redação mais sistemática, que foi editado como um mosaico de cenas. Dessa forma, ao longo do desenvolvimento da pesquisa, as cenas foram escritas diversas vezes, em diferentes formatos, a partir de diferentes prismas de análise e objetivos. Na redação final, optou-se por manter as cenas na primeira pessoa do singular, dado que o escrito incide justamente nas afetações e percurso de uma das autoras na trajetória institucional.

Assim, a seleção, a escrita em primeira pessoa, o modo de apresentação das cenas, assim como os subtítulos que as antecedem, já correspondem a uma interpretação do material. Uma outra opção, nesse sentido, foi de privilegiar, em parte das cenas, pequenos recortes das histórias, "brincando" com nomes, idades ou outros fatores que poderiam levar à certeza de uma relação de continuidade entre as diferentes cenas: relatos que aparecem sem desfecho (quem sabe o fim da história?), cenas de uma mesma criança que aparece com diferentes nomes (não poderia acontecer o mesmo com outra criança?), parentescos que foram alterados (e se fosse a avó ao invés da tia?), "brincadeiras" que procuram apontar para o caráter não necessário de associações muitas vezes automaticamente feitas - 
“tinha que ser ele", "é de família..." - e para sublinhar que se tratam de questões e histórias que permanecem em aberto.

\section{O cotidiano em questão}

O abrigo, antigo orfanato, datava de algumas décadas, tendo sido criado a partir da sugestão do mentor espiritual da organização religiosa à qual se vinculava. Localizava-se no meio de um grande quarteirão; uma longa escadaria levava até a "casa" onde moravam os acolhidos. Durante muitos anos, a instituição acolheu apenas meninos; mais tarde, também meninas. De início, havia grandes quartos, onde se enfileiravam camas lado a lado. Com o posterior acolhimento de meninas, os quartos foram divididos por sexo e depois criaram-se divisórias, separando as crianças por idade.

Com o insuficiente apoio do governo Estadual, a instituição mantinha-se principalmente devido a doações de voluntários e arrecadação de verbas por meio de eventos. Em 2008, no processo de efetivação da municipalização da gestão dos abrigos, a instituição foi conveniada à prefeitura, aumentando consideravelmente o repasse de verba. Em decorrência, foi necessário fazer adaptações, de acordo com os parâmetros estabelecidos pelas legislações vigentes (Conselho Nacional dos Direitos da Criança e do Adolescente/Conselho Nacional de Assistência Social - CONANDA \& CNAS, 2008), o que implicou mudanças tanto da estrutura física da instituição quanto do quadro de funcionários e da forma de trabalho.

Fui contratada nesse período de transição. A sensação que tive, em meu primeiro dia de trabalho, foi uma aflição de me imaginar lá "todos os dias, o dia inteiro sem ver a rua". Posteriormente, ao longo de meus anos de trabalho na instituição, foi possível ressignificar essas impressões iniciais. Exatamente pelo fato de meu trabalho permitir-me "ver a rua", coloco em questão qual era meu imaginário sobre estar lá. Certamente, não apenas meu.

Mãe que é mãe...

Em uma conversa de cozinha...

(Funcionária 1): Eu acho que mãe que é mãe não deixa os filhos estarem no abrigo. Sabe, eu acho que falta amor.

(Funcionária 2): É porque é mais fácil, dá para ir no forró, não tem que levar para escola, dar bronca, isso é a gente que faz!
(Funcionária 3/eu): Mas sabe, acho que ser mãe, ter os filhos, não é só questão de querer... às vezes mesmo para querer precisa de muita coisa, precisa a gente achar que tem coisas boas, os outros dizerem que a gente pode ser bom para os filhos... porque se não a gente mesmo sente que não tem nada de bom para dar.

(Funcionária 2): É verdade, às vezes a assistente social lá do projeto do meu filho fica falando tanto no meu ouvido, que eu faço tudo errado, que nada tá bom, que eu tenho vontade de largar tudo para o alto.

(Funcionária 1): E ninguém aqui pode dizer que você não ama seus filhos!

\section{O voluntariado e seu avesso}

Quando o natal, o dia das crianças ou outras datas festivas se aproximavam, a casa ia gradativamente se transformando em um inferno. O telefone tocava sem parar, eram voluntários e instituições que desejavam conhecer a casa, trazer presentes ou organizar festas de comemoração. Como as doações auxiliavam a cobrir os gastos que o convênio com a prefeitura não abarcava, a diretriz institucional era para que aceitássemos praticamente todos os voluntários, na esperança de que algum deles oferecesse doações mais substanciais. Era como se em cada voluntário pudesse estar a salvação e, como não se sabia em qual, aceitavam-se todos. A consequência dessa aceitação irrestrita era a participação em programas sem sentido e, muitas vezes, a sobreposição de festas, presentes e visitas. Em épocas festivas, cada grupo, ou empresa, propunha-se a organizar uma festa, porém isoladamente dos outros grupos. Como a instituição também não se posicionava, o resultado eram quatro festas de natal, cinco comemorações do dia das crianças, três de páscoa. A grande maioria ruins, com um presente no final.

Com a proliferação de presentes decorrentes dessas festas, muitos eram jogados no terreno vizinho ou quebrados instantaneamente. A crítica recaía então para as crianças, "que não sabiam dar valor", sem que se levasse em consideração o contexto e o sentido das festas, ou mesmo o que de fato elas queriam ganhar como presente. Era como se, por serem crianças "de" abrigo, devessem agradecer por qualquer presente, mesmo que repetido, mesmo que a roupa não fosse da sua numeração, mesmo que eles não quisessem mais uma bola ou preferissem um presente coletivo, quem sabe, uma bicicleta.

Uma trabalhosa conquista foi convencer a direção da instituição a se posicionar e, por que não, oferecer apenas uma festa para cada data! Questionávamos: "Alguém vai a cinco festas de natal? Como querer 
que as crianças as valorizem se a própria instituição as banaliza? Se a instituição é uma só, porque não exigir que os parceiros se juntem para produzir uma única festa? Por que nós também não poderíamos dizer o que queríamos e como queríamos?". Algumas empresas não gostaram: sentiam dividir e reduzir seu momento de reconhecimento.

\section{Riscos}

Cheguei no abrigo pela manhã e, como de costume, fui para a cozinha, tomar um café, saber como estavam as coisas. De pronto, me avisaram: "leia o livro de plantão, tem um recado sério para vocês". Era um recado de uma das educadoras, relatando que uma das adolescentes havia contado para ela uma coisa tão séria que ela não podia escrever no livro. Pedia para alguém da equipe técnica conversar com a adolescente o mais rápido possível.

$\mathrm{O}$ assunto que não podia ser escrito era de um abuso sexual. O clima de velório, culpa e angústia rapidamente se instalou, principalmente entre os funcionários: "como não percebemos?", "que relação tínhamos com as crianças que elas demoraram tanto para nos contar?". Os funcionários mais antigos nos "consolavam", que "aquilo" sempre havia acontecido: alguns adolescentes, que já tinham saído da instituição, haviam contado para eles. Muito provavelmente, aquele garoto também poderia ter sofrido abusos e que, agora, repetia com os menores o que haviam feito com ele.

O que não podia ser escrito, o que demorou para ser contado, durante muito tempo também não havia sido ouvido, embora parecesse que sempre estivesse lá, conhecido por todos. Lidar com o ocorrido era muito delicado. Foi necessário comunicar a Prefeitura e o Poder Judiciário sobre o processo de todas as crianças envolvidas, e relatar aos familiares e à presidência da instituição.

Mais do que tudo, significava lidar com o risco dentro do próprio abrigo.

\section{Restituições}

Maria do Socorro, tia de uma criança acolhida, certa vez, perguntou-me: "mas você acha que tem alguma chance do juiz dar a guarda de minha sobrinha para uma pessoa assim que nem eu, pobre e sem estudo?". Respondi que sim, que achava que tinha. Perguntei por que ela achava que não. "Filho deve ficar com a mãe, não deve? Pois mãe é mãe", ela me respondeu, pedindo minha confirmação. "Nem sempre, deve ficar com quem pode cuidar", argumentei.
Já acompanhava o caso há alguns meses. Taís, no início de sua adolescência, havia delatado uma traição da mãe para seu atual companheiro e, em decorrência, foi morar com sua tia. "Morar com a tia" já havia ocorrido algumas vezes em sua vida, em geral como forma de resolução de um conflito com a mãe. Maria do Socorro, um dia, foi queixar-se ao Conselho Tutelar de que sua sobrinha não a respeitava, e eles decidiram pelo acolhimento da menina. A tia, entretanto, relatava que não havia entendido as consequências dessa ação, que achava que era apenas "para dar um susto". Coincidentemente ou não, a delação da traição havia ocorrido na mesma época em que o exame de DNA solicitado pelo pai de Taís havia dado negativo e seu acolhimento no mesmo mês em que a mãe engravidara de seu atual companheiro.

Em um outro dia, Maria do Socorro me perguntou se já que o DNA havia mostrado que seu irmão não era pai de Taís, se ela ainda podia ser considerada tia, se a sobrinha ainda poderia ficar com ela. Comentou, em seguida, que, na verdade, ele não era irmão de sangue dela, pois sua mãe o havia "pegado para criar" quando ele era criança. Perguntei se ela se sentia menos irmã dele por não ser de sangue, ao que ela me respondeu "de jeito nenhum!", e, em seguida, completou, "o que importa é o que a gente sente, né?". Concordei, pensando, sem coragem de falar, que tia de sangue, na verdade, ela nunca tinha sido.

Assim, quando ela me perguntou se achava que o juiz "daria" a guarda para ela, eu tinha em mente que, mais que uma questão de dificuldade de acesso a direitos sociais, que certamente existia, havia algo mais em jogo: ela também não se autorizava a ter a guarda, seja "por não ter o papel", por não ser "tia de sangue", ou porque "filho deve ficar com a mãe". Um dia, contou-me que ela própria havia dado um filho seu em sua meninice. A partir de então, foi possível pensar sua culpa decorrente, já que "filho deve ficar com a mãe": assim como outros cuidaram quando ela não pôde cuidar, por que ela não poderia cuidar agora? Será que filho deve ficar com a mãe sempre?

\section{Brincadeiras}

Repetidas vezes, desde que entrei na instituição, ele, de súbito, me perguntava: "tia, me dá um real?". Eu me incomodava com a pergunta, remetendo-me a um passado de vivência na rua que sabia que ele tinha participado. Porém, não sabia o que responder.

Nas primeiras vezes, assumia o lugar daquela que tinha um real para dar, mas dizia cinicamente "não tenho", "hoje não". Aos poucos, diante da insistência de sua pergunta, comecei a ficar brava: "para de 
ficar pedindo, já disse que não vou te dar!". O termo genérico "tia" me irritava cada vez mais e, naquela posição de "tia", continuava sem saber o que responder ao menino que me pedia um real. Depois, comecei a perguntar para que queria o dinheiro. Suas respostas, entretanto, não tinham muita consistência, parecia que nem ele sabia o que queria comprar. Mostravam que não era o dinheiro que estava em jogo, mas o pedir: ele na posição de quem pedia, eu na posição incômoda de não saber o que dizer para não dar.

Um dia, de súbito, respondi algo inusitado, fiz graça com sua pergunta. Ele se surpreendeu, depois achou graça. Acabou virando uma brincadeira entre nós.

Ele me perguntava: "tia, me dá um real?"

Eu respondia: "dou, mas aí você me dá dois, tá?"”.

Ele ria. Primeiro me dizia "ah! Assim não vale!".

Mas em seguida me perguntava: "e se você me der três?".

E assim a brincadeira ia, passando por quatro, dez, um milhão de reais, "o que fazer com um milhão de reais?"

Carros, aviões, viagens de volta ao mundo...

\section{O cotidiano e seus paradigmas}

A proposta de um mosaico de cenas implica fundamentalmente considerar a impossibilidade de uma unidade no cotidiano institucional: contradições, lacunas e excessos participam de sua constituição e são parte do que confere complexidade ao cotidiano das instituições. A partir dessa compreensão, há múltiplas possibilidades de discussão das cenas; por isso, ela será realizada apenas em função da hipótese central discutida: de que as práticas sociais cotidianas são atravessadas por modelos de práticas que constituíram a assistência à infância e que sua problematização pode permitir um outro lugar nas ações desse campo.

Partindo da suposição de que os sujeitos produzem discursos, ao mesmo tempo em que são produzidos por eles, a identificação ou não a esses lugares instituídos discursivamente implica diferentes posições subjetivas, assim como legitima ou fricciona os discursos e as práticas em questão. Tendo em vista esse posicionamento, um eixo privilegiado dessa discussão reside nas posições, aderidas ou friccionadas, dos sujeitos nesses discursos.

O movimento relatado nas datas festivas pode ser visto como paradigmático de uma relação que fixa as posições em torno da ajuda, características do modelo caritativo. As posições constituídas por esse discurso são fixadas em torno deste eixo central: quem pode ajudar e quem precisa de ajuda. A escolha e o poder estão no primeiro lado: quem pode ajudar, ou seja, quem não é obrigado, faz por vontade própria e pode escolher não fazer. A necessidade, em contrapartida, está no segundo lado: a quem a precisa, pouco cabe a escolha, visto que a necessidade é imperativa.

Minicelli (2004), ao discutir os serviços de assistência à infância na Argentina, problematiza a oferta de "ajuda" recorrente nas ações desse campo. Para a autora, essa oferta mantém a concepção presente na ideia de minoridade, de alguém menor que precisa ser ajudado. Referindo-se ao lugar esperado das crianças e adolescentes diante das ações institucionais, escreve Minicelli (2004, p. 118):

el precio que el "menor" debe pagar por ello [a satisfação de suas necessidades] es la adaptación a la arbitrariedade de normas estabelecidas por la tradición en minoridad. Su deber es agradecer lo que recibe y quedarse en el lugar que se le asigna.

$\mathrm{Na}$ cena, os voluntários, à primeira vista, são vistos apenas como pessoas dispostas a ajudar o outro, tendo em vista a suposta carência das crianças. Porém, quando as crianças quebravam ou não davam o valor esperado (pelos voluntários) aos brinquedos doados, introduziam uma ruptura ao curto-circuito dar-receber, que colocava em questão não apenas o posicionamento delas - agradecer o que recebem e permanecer no lugar de carência e falta que lhes é atribuído - quanto o da instituição, como provedora. Pode-se interpretar a quebra dos brinquedos como um movimento das crianças de produzir fissuras nesse curto-circuito, ao mostrarem a possibilidade de outras circulações. No entanto, essa situação, invariavelmente, gerava indignação. A quebra da satisfação e reconhecimento esperados colocava em xeque a, até então, inquestionável, ajuda: o que faziam lá se o que tinham a dar estava sendo quebrado?

Se o abrigo se organizava a partir das posições de reconhecimento em torno da relação de ajuda e carência, definindo quem tem e quem não tem, outro polo organizador da instituição refere-se à localização do risco e da proteção, eixos característicos do modelo filantrópico.

A função institucional do abrigo, como lugar de cuidado e proteção, estabelecida pelas legislações e almejada pelos atores institucionais, funda, ao mesmo tempo, aspectos que são depositados como representantes do fora. $\mathrm{O}$ abrigo era considerado por todos um lugar onde as crianças estariam protegidas. 
Já as violências, maus tratos e negligências eram temáticas esperadas - visto que eram essas ocorrências que legitimavam a existência da instituição - em parentes das crianças que estavam acolhidas, ou mesmo em outros equipamentos públicos, sempre no fora. Assim, delimitava-se tanto a função da instituição quanto as representações esperadas às crianças, aos familiares e aos agentes institucionais.

Se essa delimitação entre dentro e fora exerce função necessária à instituição, uma reflexão a se fazer é sobre suas implicações nas relações estabelecidas no cotidiano dos serviços. Scarparo (2008) sugere que a delimitação da clientela definida pelos critérios de ingresso pode proporcionar uma colagem da identidade do sujeito a esse lugar definido como público alvo do serviço, dificultando ao sujeito transcendê-lo. Outra questão refere-se à permeabilidade ou à possibilidade da instituição e seus agentes suportarem fricções nas identidades e relações estabelecidas.

A cena que relata os mal-estares decorrentes da descoberta de abusos sexuais dentro da instituição é provocadora no sentido de questionar a atribuição do risco ao exterior da instituição, apontando para a fragilidade dessas divisões. Não raro, em outras situações nas quais apareciam episódios de violências, por exemplo, tais ocorrências eram explicadas por se tratar de uma criança "que era de rua" ou pela repetição das crianças de seus passados. Explicações que buscavam manter essa impermeabilidade entre dentro e fora, assegurando a sustentação da instituição e também das identidades dos sujeitos relacionados. A descoberta da ocorrência de abusos sexuais, dentro da instituição, praticada por um adolescente que morava desde pequeno no abrigo, provocou na equipe a impossibilidade de sustentar essa impermeabilidade. Há um lugar a salvo de riscos? Nesse sentido, as dificuldades encontradas pela equipe diante dessa situação em grande parte se relacionam à necessidade que lidar com o ocorrido impõe colocar em questão a posição do abrigo e de cada um. Não por acaso era um assunto tão difícil e tão pouco falado.

Sobre as concepções de vulnerabilidade social ou situação de risco social, Cruz (2006) afirma que elas vêm acompanhadas de uma atribuição de probabilidades às incertezas, que envolve diferenciações, no caso entre famílias em risco e famílias (ou instituições) em que não pensamos estar em situação de risco, ou entre famílias vulneráveis ou não. Para a autora: "na base desse binarismo está a crença de que cada conceito se opõe ao outro, ocupa um território separado, trabalhando no sentido da homogeneização" (p. 102). Nesse aspecto, na medida em que os campos são internamente homogêneos em relação uns aos outros, operam como se apenas houvesse diferenças entre eles. Se o risco está fora, ele não pode estar dentro.

$\mathrm{Na}$ cena em que algumas funcionárias conversavam na cozinha sobre as mães das crianças institucionalizadas, afirmando que elas não eram uma "mãe que é mãe", ou seja, uma mãe "de verdade", estabeleciam uma divisão entre o dentro e o fora institucionais: entre elas e outras mães que tinham seus filhos sob sua guarda, de um lado, e as mães das crianças que estavam no abrigo, de outro. Nessa cena, nota-se como o contato próximo com o outro, com suas marcas, dores e histórias, nem sempre é possível. Em contrapartida, a partir da intervenção feita, de propor pensar como algumas mães são destituídas desse lugar de mãe, foi possível ao grupo rever essa divisão: também uma das funcionárias pensava em largar tudo para o alto, e isso não a fazia gostar menos de seus filhos ou ser menos mãe.

Mostra-se, assim, como o cotidiano institucional constitui-se a partir de distintos paradigmas que atribuem posições específicas aos envolvidos. Seu reconhecimento nos diversos momentos do dia a dia institucional pode permitir o questionamento dessas atribuições, proporcionando a circulação e a criação de novos lugares a serem ocupados. Minicelli (2004), inspirada no mito de Ariadne, traz uma bonita e impactante imagem sobre as redes de serviços de assistência à infância: um labirinto, com suas muitas portas de entrada, mas cujas saídas são difíceis de ser encontradas, muitas vezes condenando o sujeito a um curto-circuito, com suas restritas possibilidades de experimentação e identificação. A ética dos saberes psis nessas instituições incide justamente na criação de saídas, buracos e atalhos nesse labirinto. São caminhos singulares percorridos pelas crianças, adolescentes, famílias e profissionais desse campo que, acompanhados uns dos outros, podem permitir encontros e circulações por novos lugares, quem sabe para fora do labirinto.

\section{Universalidade e singularidade: atalhos ao labirinto}

Pensar nas relações entre subjetividade e políticas públicas tem sido alvo de pesquisas, na intenção de compreender os efeitos das políticas públicas na vida das pessoas, bem como as lacunas que se estabelecem entre os âmbitos político-jurídico e técnico-assistencial (Scarcelli, 2011).

Abordar essa relação implica uma visão de subjetividade em íntima relação com o social, entendido aqui como o jogo de processos históricos, 
políticos, econômicos e culturais. Assim, quando Maria do Socorro perguntou se o juiz daria a guarda de sua sobrinha para uma pessoa que nem ela, pobre e sem estudo, certamente estava em questão sua sensibilidade em perceber que, muitas vezes, o reconhecimento dos direitos em relação a essa parte da população não apenas diz respeito às leis em vigor, mas também à comunidade de valores. Porém, é também em relação ao modo singular como ela se apropria e se identifica a essa condição de desvalorização que sua pergunta incide. Ignorar essa dimensão, da relação por ela construída entre sua história e seu lugar no discurso social, implica restringir as possibilidades de escuta e intervenção.

Nessa cena fica evidente a função organizadora do testemunho como estratégia de restituição da autoridade e das possibilidades de ação da tia. Diante do peso e da culpa carregada por escolhas forçadas, aquela senhora se organizava em suas relações mantendo-se nesse mesmo circuito, na mesma posição. Como autorizar-se a cuidar? Suas perguntas em busca de uma confirmação ou de uma autorização do outro mostravam, mesmo que do avesso, a possibilidade de uma alternativa ao curtocircuito. "Filho deve ficar com a mãe, não deve?", "eu ainda posso ser considerada tia?", e ainda "você acha que tem alguma chance do juiz dar a guarda a uma pessoa como eu, pobre e sem estudo?" mostram a existência de um momento reticente e vacilante do sujeito frente à confirmação do que acredita-se que já se sabe, e a pergunta destinada ao outro revela uma esperança de não confirmação, de possibilidades de outras circulações. Caminhos pelos quais só é possível entrar acompanhado, com aval e presença do outro, e aí reside a função do testemunho.

Para que as falas dessa tia possam ser assim escutadas é preciso ir para além da forma como essas questões são, à primeira vista, colocadas. É certo que nessa história há, por exemplo, uma inadequação da função do Conselho Tutelar, ao sugerir o acolhimento institucional como primeira alternativa à queixa de desobediência. Porém, há também um posicionamento dessa tia que, da mesma forma em que pedia uma (não) confirmação de suas sentenças, ao solicitá-la ao Conselho Tutelar, obtendo uma confirmação apressada, ao invés de um espaço de escuta. A questão a ser conversada não dizia apenas respeito à possibilidade de efetivação de direitos sociais, mas como era para essa tia, diante de sua história, sentir-se autorizada como mãe, tia e cidadã.

Assim, entende-se que, se a concepção de universalidade presente no Estado de bem-estar social para assuntos ligados à infância é fundamental para a construção de políticas públicas e práticas sociais éticas e democráticas, os saberes psis, ligados à subjetividade e à singularidade, podem trazer contribuições fundamentais para efetivação desses marcos legais, na medida em que incidem sobre a significação e a apropriação desses marcos para cada um. Podem favorecer também a reflexão sobre os detalhes cotidianos, bem como pôr em relevo as sutilezas dos acompanhamentos e os caminhos e estratégias de vida construídas, como atalhos, pelos sujeitos: testemunhos, partilhas, o humor, as brincadeiras...

Nessa linha, é importante retomar uma cena que a princípio passou desapercebida. Entre tantas histórias, indignações, incômodos e violações, a história do menino que pedia um real durante algum tempo mal foi lembrada. Repetidamente ele questionava sobre o lugar da psicóloga para ele e a instituição: daria a ele um real? As respostas foram sendo dadas a partir de diferentes lugares: daquela que tinha, mas dizia que não, daquela que se irritava, procurando com isso cessar os pedidos e daquela que perguntava o que ele queria, como se a resposta a ser dada dependesse da justificativa dele.

As respostas também presumiam diferentes significados para ele e seu pedido. O primeiro incômodo supunha uma relação direta entre seu passado na rua e sua fala. Imaginava-se, assim, a existência de uma pura repetição, que explicaria toda a cena, sem que fosse necessário incluir-se nela, pensando no sentido daquela fala no contexto da instituição. Nos momentos em que ele era questionado para que queria o dinheiro, supunha-se uma intencionalidade, a qual ele respondia apontando apenas para seu desejo: não sabia bem o que queria fazer e nem isso lhe importava, só queria querer!

Foi a partir da consideração dessa dimensão que foi possível surgir a brincadeira, sem supor a repetição de um passado em que só havia um menino, sem avaliar a pertinência do que pedia e deslocando a questão do que deveria ser dito para não dar um real. De alguma forma, a brincadeira incidia nas posições atribuídas, mais no que estava sendo pedido ou no que deveria ou não ser dado: se ele podia pedir algo, por que o outro não poderia pedir também?

$\mathrm{O}$ que se construiu nessa brincadeira foi algo que dizia respeito àquela relação construída. Por mais que algumas crianças vissem a brincadeira e procurassem reproduzi-la, o efeito, obviamente, não era o mesmo. Para as outras, foram sendo criadas e construídas outras marcas, que diziam respeito a cada uma e a cada relação que criaram na instituição: da menina que fazia charada com seu nome na hora de se apresentar, do menino que coletava folhas e guardava no meio dos 
livros, do menino que adorava brincar que estava preso nos braços da cozinheira e que só saía com um beijo, histórias que marcaram não apenas por suas diversas e insistentes violações, mas por suas importantes sutilezas, por seus detalhes.

\section{Referências}

Caponi, S. (2000). Da compaixão à solidariedade: uma genealogia da assistência médica. Rio de Janeiro: Editora Fiocruz.

Chambouleyron, R. (2000). Jesuítas e as crianças no Brasil quinhentista. In M. Del Priori (Org.), História das crianças no Brasil ( $2^{\mathrm{a}}$ ed., pp. 55-83) São Paulo: Contexto.

Conselho Nacional dos Direitos da Criança e do Adolescente/ Conselho Nacional de Assistência Social. (2008). Orientações técnicas para os serviços de acolhimento para crianças e adolescentes. Brasília: Autor.

Constituição da Republica Federativa do Brasil. (1988). Acesso em 31 de janeiro, 2013, em http://www.planalto.gov. br/ccivil 03/constituicao/constituicao.htm

Cruz, L. R. (2006). (Des)articulando as politicas públicas no campo da infância: implicações da abrigagem. Santa Cruz do Sul, RS: EDUNISC.

Decreto n. 17.943. (1927, 12 de outubro). Código de Menores. Acesso em 31 de janeiro, 2013, em http://www.planalto.gov. br/ccivil_03/decreto/1910-1929/D17943A.htm

Donzelot, J. (1980). A polícia das famílias (M. T. da Costa, Trad.; J. A. Guilhon Albuquerque, Rev. Técnica). Rio de Janeiro: Graal.

Fávero, E. T., Vitale, M. A. F., \& Baptista, M. V. (Orgs). (2008). Famílias de crianças e adolescentes abrigados: quem são, como vivem, o que pensam, o que desejam. São Paulo: Paulus.

Foucault, M. (1970). A ordem do discurso. Aula Inaugural no Colègge de France. São Paulo: Edições Loyola.

Guirado, M. (2009). A análise institucional do discurso como analítica da subjetividade. Tese de livre docência, Instituto de Psicologia, Universidade de São Paulo, São Paulo.

Lei Federal n. 8.069. (1990, 13 de julho). Estatuto da Criança e do Adolescente. Acesso em 24 de julho, 2012, em http:// www.planalto.gov.br/ccivil 03/leis/18069.htm

Leôncio, W. A. H. (2009). Consultas terapêuticas de crianças abrigadas e seus pais: uma investigação dos vínculos familiares. Tese de Doutorado, Instituto de Psicologia, Universidade de São Paulo, São Paulo.

Marcílio, M. L. (2006). História Social da criança abandonada. São Paulo: Hucitec.

Minicelli, M. (2004). Infancias públicas. No hay Derecho. Buenos Aires: Noveduc.

Ministério do Desenvolvimento Social e Combate à Fome. (2005). Norma Operacional Básica/Sistema Único de Assistência Social (NOB/SUAS). Brasília: Autor.

Pino, A. (1990). Direitos e realidade social da criança no Brasil. A propósito do "Estatuto da Criança e do Adolescente". Revista Educação \& Sociedade, ano XI, 36, 61-79.

Rizzini, I. (2011). O século perdido: raizes históricas das políticas públicas para a infância no Brasil ( $2^{\mathrm{a}} \mathrm{ed}$. rev.). São Paulo: Cortez.

Rizzini, I. \& Pilotti, F. (2011). A arte de governar crianças: a história das políticas sociais, da legislação e da assistência à infância no Brasil ( $3^{\mathrm{a}}$ ed.). São Paulo: Cortez.
Scarcelli, I. R. (2011). Entre o hospicio e a cidade: dilemas no campo da saúde mental. São Paulo: Zagodoni.

Scarparo, M. L. D. E. (2008). Em busca do sujeito perdido: a psicanálise na assistência social, limites e possibilidades. Dissertação de Mestrado, Universidade Federal do Rio Grande do Sul, Porto Alegre.

Serra, L. N. (2011). Infância perdida: a concepção de "menores anormais" na obra Pacheco e Silva. Dissertação de Mestrado, Instituto de Psicologia, Universidade de São Paulo, São Paulo.

Silva, E. R. A. (2004). O perfil da criança e do adolescente nos abrigos pesquisados. In E. R. A. Silva (Org.), O direito à convivência familiar e comunitária: os abrigos para crianças e adolescentes no Brasil (pp. 41-70). Brasília: IPEA/CONANDA.

\section{Agradecimento}

Ao CNPq pelo apoio e financiamento - Proc. no. 134229/2011-8.

Submissão em: 20/10/2013

Revisão em: 30/03/2014

Aceite em: 20/04/2014

Carina Ferreira Guedes é Psicóloga e Mestre em Psicologia Social pela Universidade de São Paulo. Endereço: Rua Tucuna, 146, casa 2, Pompeia, São Paulo/ SP, Brasil. CEP 05021-010. E-mail: carinafguedes@gmail.com

Ianni Regia Scarcelli é Professora Doutora do Departamento de Psicologia Social e do Trabalho do Instituto de Psicologia da Universidade de São Paulo. E-mail: iannirs@usp.br

\section{Como citar:}

Guedes, C. F. \& Scarcelli, I. R. (2014). Acolhimento institucional na assistência à infância: o cotidiano em questão. Psicologia \& Sociedade, 26(n. spe.), 58-67. 